China Perspectives

$2010 / 4 \mid 2010$

Rural Migrants: On the Fringe of the City, a Bridge to the Countryside

\title{
The Economic Situation of Rural Migrant Workers in China
}

Shi Li

\section{CpenEdition}

\section{Journals}

Édition électronique

URL : http://journals.openedition.org/chinaperspectives/5332

DOI : 10.4000/chinaperspectives.5332

ISSN : 1996-4617

Éditeur

Centre d'étude français sur la Chine contemporaine

Édition imprimée

Date de publication : 15 décembre 2010

ISSN : 2070-3449

\section{Référence électronique}

Shi Li, «The Economic Situation of Rural Migrant Workers in China », China Perspectives [En ligne]

2010/4 | 2010, mis en ligne le 01 décembre 2013, consulté le 28 octobre 2019. URL : http://

journals.openedition.org/chinaperspectives/5332 ; DOI : 10.4000/chinaperspectives.5332

(c) All rights reserved 
(1)

The Economic Situation

of Rural Migrant Workers

in China

SHI LI

ABSTRACT: This paper examines the current economic situation of rural migrant workers in China. The paper provides some descriptive statistics on their regions of origin, their destinations, and the sectors in which they are employed, as well as on their age, sex and level of education. The paper also discusses the difficult working conditions of many rural migrant workers in the Chinese labour market, in particular their low wages, the problems of wage arrears, the lack of written contracts, the long working hours, the inadequate social security coverage, and the difficulties they face in accessing public services.

\section{Introduction}

C hina was primarily an agricultural economy in the 1970s, with the majority of the population residing in rural areas ${ }^{(1)}$. The rural population comprised 82 percent of the total population in 1978, when China launched its economic reforms. The rural reforms in the late 1970s and early 1980s, characterised by de-collectivisation of land, provided a strong incentive for rural households to produce food more efficiently, but the problem of labour surplus in agriculture gradually appeared and became increasingly challenging. One estimate was that there were about 240 million of surplus labourers in rural China in the 1980s. ${ }^{(2)}$ One solution to this problem favoured by the Chinese government was to develop township-village enterprises (TVEs) to absorb the surplus labour. As a result, a large number of rural labourers transferred to TVEs. However, urban reforms, especially the restructuring of state-owned enterprises (SOEs), raised the competitiveness of urban industry, which put TVEs at a disadvantage in market competition and led to their slow growth in the 1990s.

With the slow-down in employment in TVEs, rural labourers attempted to move to the cities for employment opportunities. There was a big increase in the number of rural migrant workers in the early 1990s, from around 30 million in 1989 to 62 million in 1993. This process was not smooth, however. Starting in the mid-1990s, reform of the SOEs led to lay-offs and unemployment for millions of urban workers. The unemployment rate rose to over 10 percent in urban China and challenged the government policy of social stabil- ity. Facing rising unemployment rates, municipal governments implemented a series of regulations to limit the employment of rural migrants in urban enterprises. As a result, the number of rural-urban migrant workers did not rise as steadily in the late 1990s as it had in the early 1990s.

Entering the new century, the Chinese government realised that measures against the movement of rural migrants to urban areas had generated many negative effects on the development of the rural economy and on economic growth generally. In more recent years the central government has issued a number of documents appealing to local governments to improve services for rural migrant workers. ${ }^{(3)}$ Implementation of the policy favouring rural labour mobility and the provision of services to rural migrants resulted in the number of rural migrant workers in urban areas reaching unprecedented levels. This trend was interrupted temporarily by the financial crisis in late 2008, which caused more than 10 million rural-urban migrant workers to lose their urban jobs at the beginning of 2009. ${ }^{(4)}$ Fortunately, the Chinese government's macroeconomic policy in response to the finan-

1. The author is grateful for comments from Dr. Sylvie Démurger.

2. Cheng Wang, "Employment transition in China: From hidden unemployment and underemployment to efficiency-oriented employment," Economic Research (in Chinese), no. 5, 1996

3. For instance, document Number 5 of the State Council in 2006 explicitly required loca governments to implement the guidelines of equal opportunities in employment and rights-protection for rural migrant workers.

4. While there are different estimates for the number of migrant workers losing jobs at the beginning of 2009, data from the Rural Migration Survey conducted by the National Bureau of Statistics indicate that the number is about 12 million. Laiyun Sheng, Ran Wang, and Fang Yan, "Impact of the global financial crisis on employment of rural migrant workers," 2009, http://www.hadc.gov.cn/info/cms/template_InfoShow /hndczd/infoshow.jsp?columnld=170\&infold=3545 . 
Table 1. Migrant workers and employment in urban China

\begin{tabular}{l|c|c}
\multirow{2}{*}{$\begin{array}{l}\text { City } \\
\text { Shanghai }\end{array}$} & Number of rural migrants & As percentage of the total sample (\%) \\
\hline Nanjing & 677 & 10.33 \\
\hline Wuxi & 522 & 7.96 \\
\hline Hangzhou & 282 & 4.3 \\
\hline Ningbo & 550 & 8.39 \\
\hline Hefei & 283 & 4.32 \\
\hline Bengbu & 426 & 6.5 \\
\hline Zhengzhou & 239 & 3.65 \\
\hline Luoyang & 476 & 7.26 \\
\hline Wuhan & 256 & 3.91 \\
\hline Guangzhou & 495 & 7.55 \\
\hline Shenzhen & 522 & 7.96 \\
\hline Dongguan & 342 & 5.22 \\
\hline Chongqing & 403 & 6.15 \\
\hline Chengdu & 565 & 8.62 \\
\hline & 516 & 7.87 \\
\hline
\end{tabular}

Sources: RUMS (2007).

cial crisis led the number of rural migrant workers to rebound to pre-crisis levels by the end of 2009. ${ }^{(5)}$

There have been many studies on rural migration issues in China over the last two decades. It is not the intention of this paper to provide a survey of the literature of China's rural migration studies, which has already been accomplished by $\mathrm{Z}$. Zhao. ${ }^{(6)}$ Few studies, however, provide a comprehensive picture of the rapid change in rural migration in terms of size, distribution, wage levels, social security coverage, work conditions, and relevant policies that has taken place since the mid 1980s. This paper aims to update information and data that have become available in recent years.

The data used in this paper come from two sources: the China Household Income Project Survey (CHIPS) in 2002 and the Rural-Urban Migrant Survey (RUMS) conducted by the Project of China Rural Migration in 2007. The first survey was designed to investigate household income and income inequality in China as a whole, and includes 2,000 rural-urban migrant households from 12 provinces. The size of the RUMS sample in the 2007 survey is 5,000 migrant households in 15 cities selected from nine provinces. As ruralurban migrants are concentrated in large cities, all the provincial capital cities, plus one or two medium-sized cities in each of the provinces, were selected for the surveys. ${ }^{(7)}$ The distribution of the migrant samples across cities can be found in Table 1. For the analysis in this paper, migrants aged 16-60, employed, and with positive income were selected.
This paper also reports some results from the Rural Migration Survey conducted by the National Bureau of Statistics (RMS_NBS). This survey has been conducted since 2003 as a complementary survey to the NBS regular household survey. The RMS_NBS surveys the same households as the regular survey, but with a set of different questions concerning out-migration of household members and a special questionnaire designed for village heads. The RMS_NBS covers around 68,000 households and 7,100 villages in 31 provinces or province-level mega-cities.

The remainder of this paper is organised as follows. The second section discusses changes in policies for rural migration and migrant workers in urban areas. The third section provides a description of the basic facts of rural migration in terms of size, demographic characteristics, and regional and industrial distribution. The problems and discrimination faced by rural migrant workers are investigated in the fourth section. The paper is concluded in the last section.

5. National Bureau of Statistics, Report on the rural migrant workers monitoring survey, Rural Department of NBS, 2010, http://www.stats.gov.cn/tjfx/fxbg/t20100319_402 628281.htm.

6. Zhong Zhao, "Migration, Labor Market Flexibility, and Wage Determination in China: A Review," The Developing Economies, vol. 43, no. 2, 2005, pp. 285-312.

7. The detailed description of the surveys can be found in Shi Li, Chuliang Luo, Zhong Wei and Ximing Yue, "The 1995 and 2002 Household Surveys: Sampling Methods and Data Description," in Bjorn Gustafsson et al., Inequality and Public Policy in China, Cambridge University Press, 2008, pp. 337-353, and for the year 2007 on the following website: http://rumici.anu.edu.au/joomla/index.php?option=com_content\&task=view\&id=49\& Itemid=52. 


\section{Changes in policies on rural migration and migrant workers}

Official policy on rural migration has changed gradually over the last three decades. In the pre-reform period, tight restrictions were placed on rural migration and labour mobility. Rural-urban migrants were called the "blind floating population," meaning that their mobility was not legally recognised socially and administratively. The government enacted many measures to curb rural migration. Food rationing implemented by providing food coupons to urban residents rather than to the rural populace made it impossible for rural-urban migrants to survive in cities. Some rural-urban vagrants and job-seekers detained by police were forced to return to their hometowns. Moreover, the household registration system (hukou), implemented in the late 1950s and classifying all individuals as either rural or urban residents, became an instrument for identifying those who came from rural areas. It was extremely difficult for someone to change a rural hukou to an urban one.

Improved labour productivity resulted from agricultural reforms, and the baby boom of the 1950s and 1960s led to a growing labour surplus in rural areas in the 1980s. ${ }^{(8)}$ The Chinese government recognised this problem and encouraged the development of rural industry to absorb surplus labour. This resulted in the rapid development of TVEs in terms of output and employment; by the end of the 1980s, the number of workers employed by TVEs reached about 95 million. ${ }^{(9)}$ At the same time, rural people were encouraged to move to small towns rather than to cities. The strategy at this stage was referred to as the "development of small towns." One slogan was "li tu bu li xiang" (leaving the land but not the village), which vividly reflected the principle of the strategy. The government adopted this strategy out of concern that a flood of rural-urban migrants would cause major urban areas to develop problems such as traffic congestion, rising crime, asylum, and social conflicts, as had happened in most developing countries.

Entering the 1990s, the growth of employment in TVEs slowed due to strong competition from foreign-funded enterprises and reformed SOEs, but the surplus in rural labour continued increasing, providing even greater impetus for rural people to move to cities for employment. Meanwhile, the central government's attitude toward rural migration changed from negative to ambivalent, allowing municipal governments to develop their own policies on rural migration. This resulted in rural migration policies differing from one city to another. If a city faced a labour shortage, its pol- icy favoured the employment of rural migrants, as in the case of Shenzhen, a Special Economic Zone in Guangdong. Even in the mid-1990s, residents with local urban hukou accounted for less than one quarter of all Shenzhen residents, with over three quarters coming from outside. ${ }^{(10)}$ As most large cities began to face serious problems of unemployment and increasing numbers of laid-off workers due to economic restructuring from the mid-1990s, policies on the employment of rural migrants turned more negative and restrictive in those cities. For instance, the Beijing municipal government issued a guideline in 1998 that listed jobs not open to rural migrants and declared measures to punish enterprises

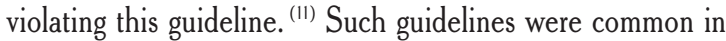
other large cities in the late 1990s. Thus, the employment of rural migrants was increasingly concentrated in industries and enterprises that local urban people did not want to join or in jobs that local urban residents avoided.

At the beginning of the new century, with rapid economic growth and decreasing pressure from unemployment in urban areas, city governments have been gradually loosening restrictions on rural migration. The number of migrant workers in urban areas has reached historic levels recently, although no accurate number is available. The new government formed in 2003 has put greater emphasis on rural development and the establishment of a harmonious society in China, and considers rural migration and urbanisation the most feasible solution to the problem of underdevelopment in rural areas and the development disparity between urban and rural areas. This change in the mentality of policy-makers has led to the emergence of new policies on rural migration in recent years, as summarised below.

\section{Experimental reform of the hukou system in some cities}

The principle of the reform is to bring urban and rural hukou together as one type of hukou and eliminate the function of hukou as an instrument for city government agencies to discriminate against rural people. Fujian, Liaoning, and Shan-

8. Shenghe Liu, Xiubin Li and Ming Zhang, "Scenario Analysis on Urbanization and RuralUrban Migration in China," Interim Report IR-03-036, International Institute for Applied Systems Analysis, Austria, 2003.

9. National Bureau of Statistics, China Statistical Yearbook 1992, Beijing, China Statistica Press, 1992.

10. For example, the number of residents without local urban hukou reached 3.5 million in Shenzhen in 1995, accounting for 78 percent of the city's total population (http://www.sztj.com/main/xxgk/tjsj/tjnj/ 200911202496.shtml).

11. Nansheng Bai and Hongyuan Song, Huixiang haishi jincheng (Research on China's migrant workers flowing back to the countryside), Beijing, China Financial \& Economic Publishing House, 2002. 
dong Province have abolished the dual-type hukou system and have been issuing identical hukou to urban and rural residents of their provinces since the beginning of the new century. Since then, more and more provinces have followed suit. However, hukou reform has accelerated the process of rural migration and urbanisation without greatly improving the welfare of rural migrant workers. It is still very difficult for migrant workers to gain access to the social security programs of urban enterprises.

\section{Abolition of various fees imposed on rural migrants}

To discourage rural migrants from moving to cities, municipal governments required rural migrants to hold a series of cards for which they needed to pay specific fees, especially in 1990s. Cards ranged from the temporary-residence card (zan zhu zheng) to the employment-permission card. In addition, enterprises employing rural migrant workers had to pay additional fees, ${ }^{(12)}$ such as the city-entry fee. Starting in 2004, the State Council required municipal governments to eliminate most of the cards issued to migrants and to abolish all fees relating to rural migration. ${ }^{(13)}$

\section{Partial social security provided to rural migrant workers}

As few rural migrant workers are covered by social security, the government has attempted to introduce some programs appropriate for migrant workers. On-the-job-injury insurance has been introduced for migrant workers in enterprises, either public or private, in the last two years. A pension scheme has been applied to migrant workers in some cities, but the coverage is still small because of the uncoordinated transferability of the pension from one place to another. There are also plans to introduce medical insurance for migrant workers. From the official point of view, however, given China's special situation, it will take a long time for migrant workers to enjoy the same social security as local urban workers.

\section{Providing training programs for rural mi- grant workers}

Since 2004, the Chinese government has initiated training programs for rural migrant workers. The programs are implemented by ministries, with costs shared by the central and provincial governments. For instance, the "Sunshine Proj- ect" started in 2004 with the training of 2.5 million of rural migrant workers, and aimed to train 8 million rural migrant workers each year in the period 2005-2008. The subsidy for each trainee has increased over the years. Taking Sichuan as an example, the subsidy per trainee provided by governments was 150 yuan in 2004, 160 yuan in 2005, 190 yuan in 2006 and 300 yuan in 2007.

\section{Increasing rural-urban migrant access to public services}

To encourage rural surplus labour to move out of rural areas, local governments started providing cost-free services for migrant workers in terms of job-seeking, information provision, and consultation. The State Council in 2006 set up a Joint Committee to coordinate rural migration affairs among ministries. Each county sets up an office to deal with inquiries by out-migrant workers regarding employment and rights protection. Moreover, city governments are required to take responsibility for schooling the children of migrant workers. Some cities have eliminated the additional school fees charged to migrant children, and some cities have begun opening all public schools to migrant children or providing subsidies to schools admitting migrant children. Moreover, legal assistance agencies have been established with the financial support of city and county-level governments to provide assistance to economically disadvantaged rural migrants.

\section{New Labour Contract Law}

After lengthy debate, the new law was passed by the $\mathrm{Na}$ tional People's Congress in June 2007, and implemented from 1 January 2008. The law contains specific articles concerning the protection of employee rights and wage payment. Implementation of the law was expected to benefit urban employees, especially those with temporary jobs or short-term contracts such rural-urban migrant workers, in terms of employment opportunities and payment, while increasing the labour costs of employers and enterprises. As it happened, the Law was not strictly enforced for several months following its implementation because of the financial

12. Others include a temporary residence fee (zan zhu fel), migrant management fee (liu dong ren kou guan li fel), and service fee for immigrant workers (wai lai wu gong ren yuan wu fu fel).

13. See China Development Research Foundation and United Nations Development Programme, China Human Development Report 2005, http://www.undp.org.cn/modules. php?op=modload \&name $=$ News\&file $=$ article $\&$ catid $=18 \&$ topic $=8 \&$ sid $=242 \&$ mode $=$ thre ad\&order $=0$ \&thold $=0$. 


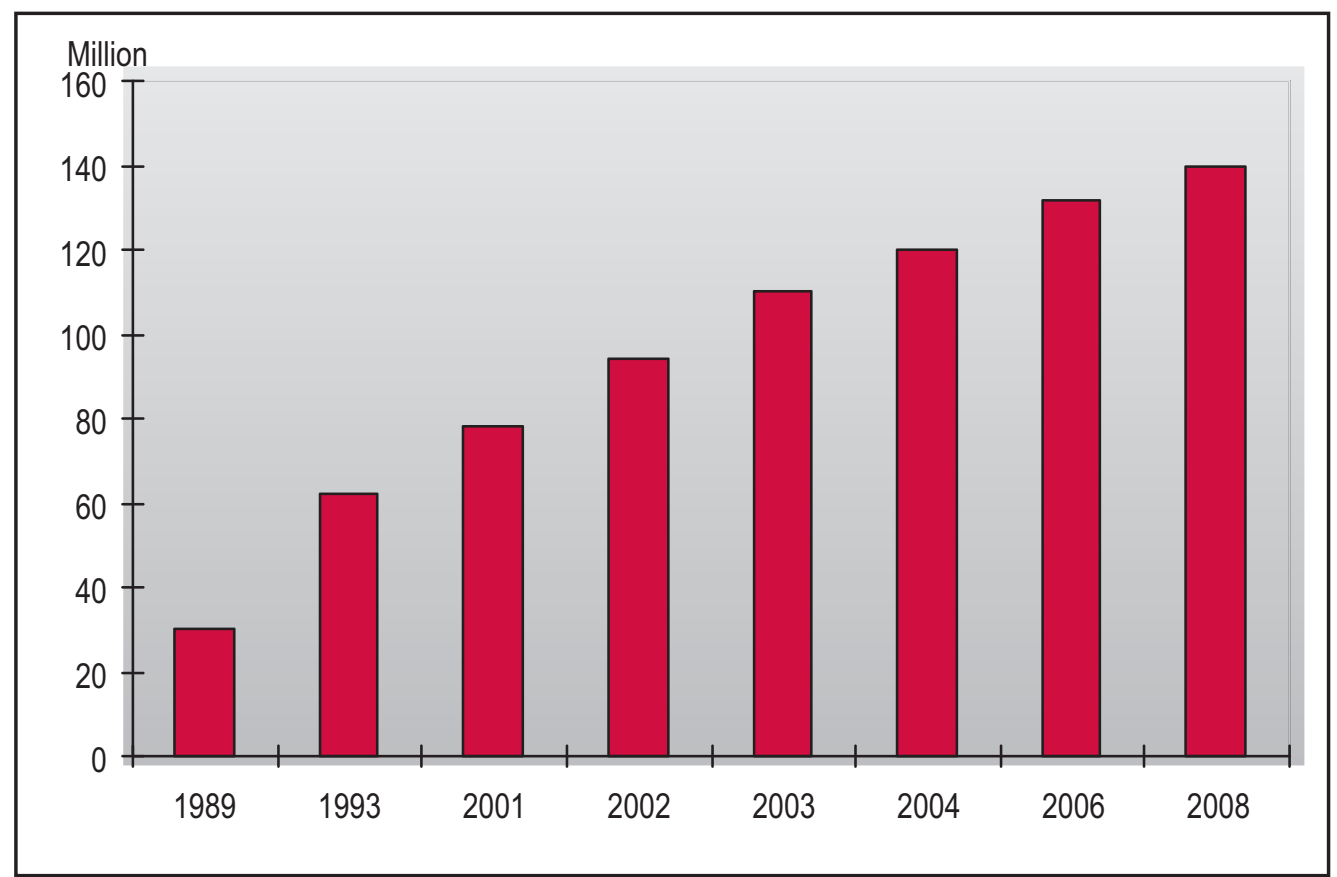

Sources: The numbers for 1989-2006 are from Shi Li, 2008, "Rural Migrant Workers in China: Scenario, Challenges and Public Policy," Working Paper No. 89, Policy Integration and Statistics Department, International Labour Office, Geneva. The number for 2008 is from National Bureau of Statistics, "The total number of rural non-agricultural workers reached 225 million at the end of 2008," 2009, http://www.stats.gov.cn/tjfx/fxbg/t20090325_402547406.htm.

crisis. It is therefore not yet clear whether the law has led to rising wages and declining demand for labour in urban China.

\section{Basic facts}

\section{Changes in the size of the rural-urban mi- grant population}

The number of rural-urban migrant workers increased with the gradual relaxation of administrative restrictions on labour mobility in urban China. To a large extent, the restrictive policy on labour migration was a major determinant of the size of the rural-urban migrant population. In the late 1970s, rural people were prohibited from moving to cities, and had difficulty surviving if they took the risk to move. As all job opportunities were controlled by city labour bureaus, and urban jobs were assigned only to people with urban hukou, it was not possible for a rural migrant to find a job in the city. The food ration system provided an additional barrier, since only urban households were entitled to food coupons. As a result, vague estimates put the number of rural-urban migrant workers at less than 2 million in the late 1970s, accounting for less than 1 percent of the total rural labour force.

At the end of the 1980s, the number rose to 30 million with the abolition of food coupons in urban areas. At the same time, private businesses and the informal sector were allowed to develop, raising the demand for rural migrant workers. Most jobs in the informal sector were characterised by the four "Ds" - dirty, draining, dangerous, and disgraceful and were disliked by urban people. The number of ruralurban migrant workers increased rapidly in the early 1990s, doubling during the period from 1989 to 1993, as shown in Figure 1. It is estimated that one third of rural migrant workers moved across provinces and two thirds within provinces in 1993. ${ }^{(14)}$ There were two driving forces pulling and pushing rural labourers to the cities. The first was the further opening of China's economy to the world market after Deng Xiaoping's speech during his southern tour in the spring of

14. Project Team of Research Office, State Council, Research report of rural migrant workers in China, China Yanshi Press, 2006. 
Figure 2. Regional distribution of rural migrants by origin and destination, 2008

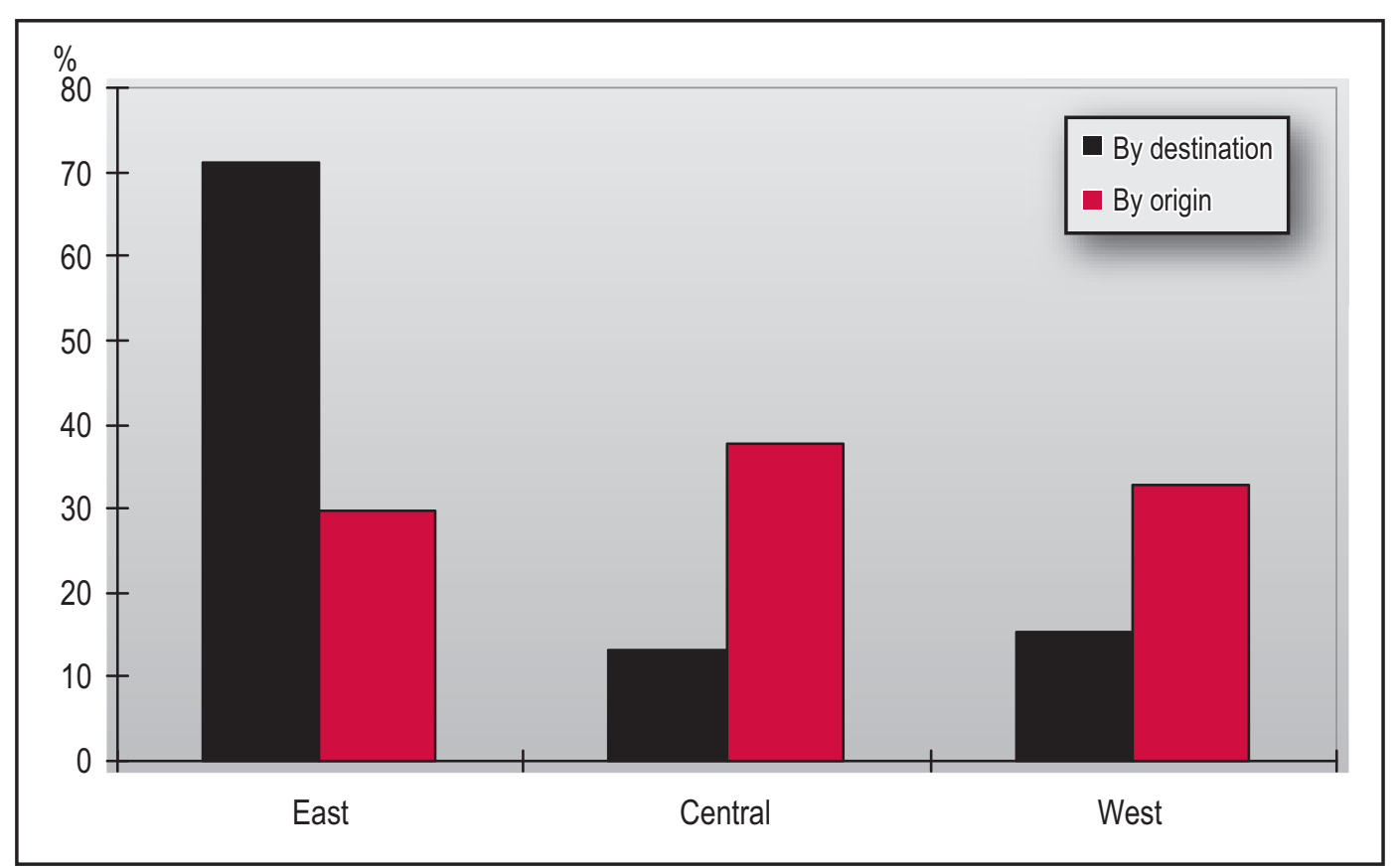

Sources: National Bureau of Statistics, "The total number of rural non-agricultural workers reached 225 million at the end of 2008," 2009, http://www.stats.gov.cn/tjfx/fxbg/t20090325_402547406.htm.

1992. Foreign capital moved into China more rapidly and generated greater demand for rural migrant workers. The second force was rapid economic growth driven by the development of the private sector and self-employment in urban areas. A majority of employees in private enterprises and the self-employed were rural migrants because jobs in these sectors were not attractive to local urban residents.

However, unemployment resulting from the restructuring of SOEs became a major problem in urban areas in the mid1990s, and city governments had to take more restrictive measures to curb the rising number of rural-urban migrant workers in order to reduce the pressure of urban unemployment in the late 1990s. Municipal labour bureaus implemented a quota system for the employment of rural migrant workers. ${ }^{(15)}$ An enterprise that employed migrant workers beyond the quota would be fined or punished. At the same time, city governments increased the moving costs for migrant workers by charging fees to both migrant workers and their employers. As a result, the number of rural-urban migrants in urban China did not significantly increased in the late 1990s. The number of migrant workers increased again as China entered the new millennium. According to figures provided by National Bureau of Statistics, there were about 140 mil- lion rural migrant workers in 2008. It should be noted that the total number of rural migrants is even larger than that of rural migrant workers, as workers often bring their families with them. ${ }^{(16)}$

\section{The distribution of migrants across regions and industries}

China is characterised by striking regional disparities along with a huge income gap between its rural and urban areas. The eastern region is more developed and has the highest income per capita, while the western region is at the bottom in terms of economic and social development. This gap causes high labour mobility across regions. It is natural to investigate the regional pattern of rural migration by looking at how large a proportion of migrant workers come from each of the three regions and how large a proportion of migrant workers go into each region. Figure 2 presents a regional distribution of rural migrant workers by region of origin and des-

15. N. Bai and H. Song, Huixiang haishi jincheng, op. cit.

16. See National Bureau of Statistics, "The total number of rural non-agricultural workers reached 225 million at the end of 2008," 2009, http://www.stats.gov.cn/tjfx/fxbg/ t20090325_402547406.htm. 
Figure 3. Distribution of rural migrant workers by industry, 2007

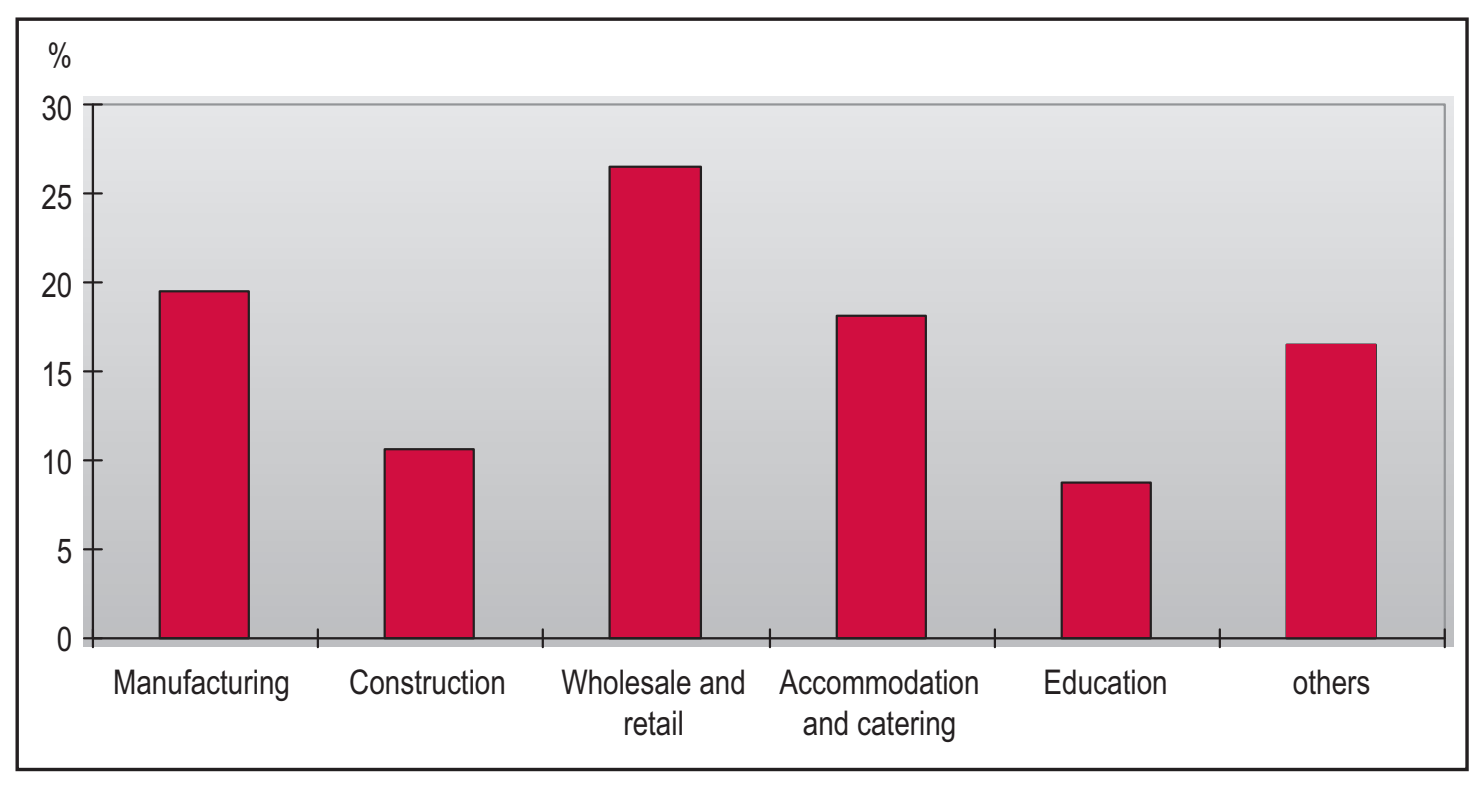

Sources: RUMS (2007)

tination region. In terms of origin, 38 percent of rural migrant workers came from the central region and nearly 33 percent from the western region in 2008. However, even within the more economically developed eastern region a large number of rural migrant workers have moved to the cities to find jobs. Rural migration is therefore a national phenomenon in today's China due to the large income disparity between urban and rural areas.

After looking at the place of origin of rural migrant workers, it is natural to ask where they go. To answer this question, we provide a description of the distribution of migrant workers by destination region in Figure 2. The eastern region is the largest receiving region, receiving over 70 percent of all rural migrant workers in 2008. Within the eastern region, Guangdong is the largest receiving province, employing more than 30 million rural migrant workers. It is quite understandable that Guangdong has become the largest receiving province, given its location and economic growth. In 2008, the per capita GDP in Guangdong province was 66 percent higher than the national average, ${ }^{(17)}$ and the province absorbed more than one fifth of China's total foreign investment in fixed assets. ${ }^{(18)}$

The next question is, "In which industries are migrant workers employed?" Rural migrant workers account for a large proportion of employees in the manufacturing and construction sectors. Data from the 2000 census indicated that 68 percent of all jobs in the manufacturing sector and 80 percent in the construction sector were held by rural migrant workers. ${ }^{(19)}$ Moreover, in the service sector rural migrant workers accounted for 52 percent of the total employment in 2000 , and the percentage is estimated to have risen since then. Figure 3 provides additional insights based on data from the 2007 RUMS. In 2007, nearly 75 percent of migrant workers were employed in four industries - manufacturing, construction, hotels and restaurants, and commerce. Manufacturing is closely related to exports, in which private and foreign-invested enterprises are concentrated. During the period 1998-2007, the number of private industrial enterprises increased from 10,667 to 177,080 , with an annual increase of 36.6 percent and value-added growth of over 50 percent in constant prices. ${ }^{(20)}$ At the same time, the number of industrial enterprises funded by foreign capital (including funds from Hong Kong, Macao, and Taiwan) increased by 155 percent, from 26,442 in 1998 to 67,456 in 2007. ${ }^{(21)}$ Unlike state-owned enterprises, private and foreign enterprises were granted greater autonomy to employ rural migrant

17. National Bureau of Statistics, China Statistical Yearbook 2009, Beijing, China Statistical Press, pp. 57 and 66.

18. Ibid., p. 192

19. Project Team of Research Office, State Council, Research report on rural migrant workers in China, op. cit., p. 7.

20. The number of private industrial enterprises and their added value can be found in National Bureau of Statistics, China Statistical Yearbook 2008, Beijing, China Statistical Press, 2008, p. 536.

21. The number of industrial enterprises funded by foreign capital can be found in National Bureau of Statistics, China Statistical Yearbook 2008, op. cit., p. 546 
Figure 4. Distribution of rural migrant workers by occupation, 2007

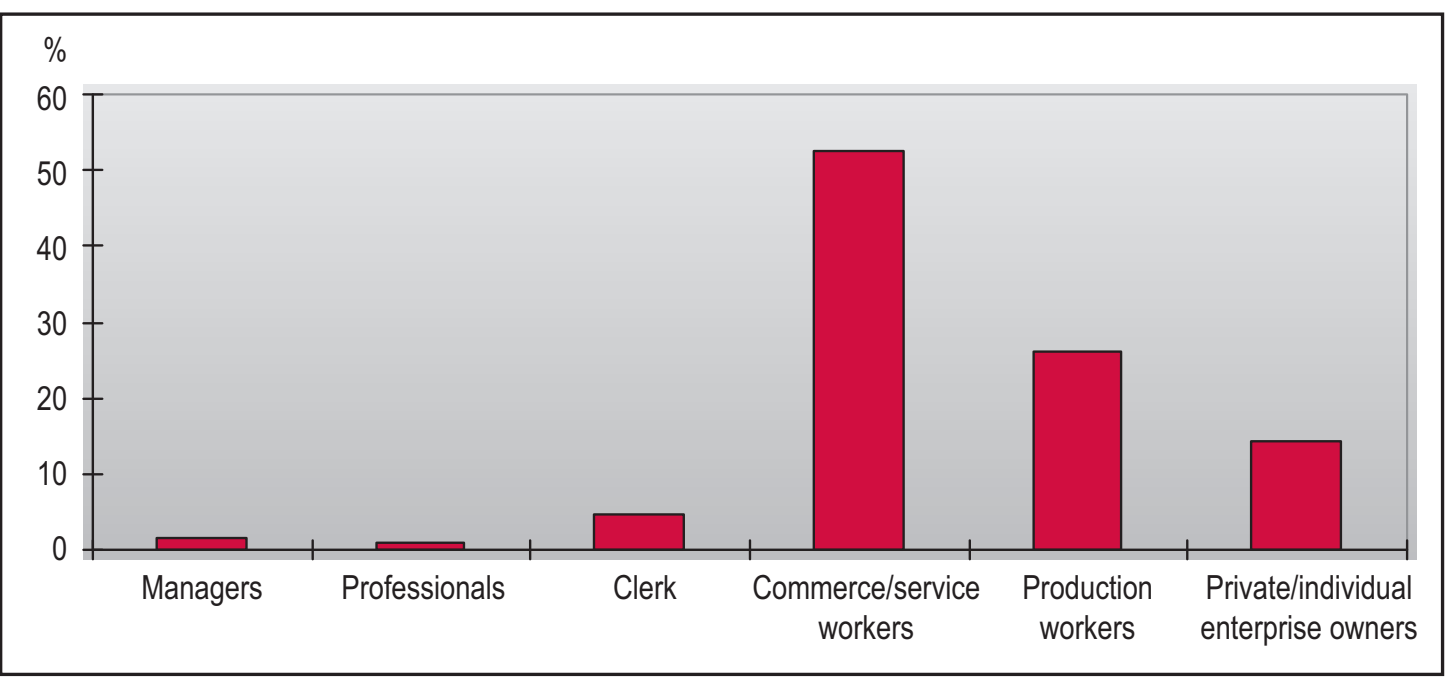

Sources: RUMS (2007).

workers from the outset. The enterprises are attracted to rural migrant workers as cheap labour, since they are paid low wages and not entitled to social security. Construction is a rapidly growing sector in China, ${ }^{(22)}$ but most jobs in this sector are intense, dangerous, and harsh and are therefore not attractive to local urban residents. This is illustrated by the fact that the number of workers in state-owned construction enterprises decreased by 45 percent during the period 1996-2007, while the number of workers in private construction enterprises increased from less than 1 million to over 23.3 million during the same period. Data from the 2007 RUMS indicate that nearly 81 percent of migrant workers were employed in private enterprises or self-employed.

Data from the 2007 RUMS also show that the majority of migrant workers are engaged in low-end occupations. As shown in Figure 4, the proportion of migrant workers employed as production workers, service workers, private enterprise owners, or self-employed reached 93 percent in the 2007 RUMS, while a small proportion of migrant workers are employed as managers, professionals, or white-collar workers. This is partly due to discrimination against rural migrant workers in the urban labour market, and partly due to the lower educational attainment of rural migrant workers. ${ }^{(23)}$

\section{The demographics of rural migrant workers}

What are the personal characteristics of rural migrant workers? Have these characteristics changed over time along with changes in demand in the labour market? To answer these questions, we need to look at age composition, gender ratio, and educational attainment. It is apparent that rural migrant workers are young, with 37 percent under the age of 26 and less than 10 percent over 45 in 2007, as indicated in the RUMS data (see Figure 5). For comparison, data from the 1 percent population sample survey in 2005 show that the 15-24 age group accounted for 22 percent and the group aged over 40 for 40 percent of the population aged 15 to 59. ${ }^{(24)}$

The gender composition of rural migrant workers shows that almost two-thirds are male. One may think this is due to discrimination against women in the urban labour market. Discrimination is one explanation, but not a major one. The lower propensity of females to migrate out is actually largely associated with the gender division of labour within households, which is heavily influenced by traditional Chinese values. Even now, Chinese women take a greater share of the responsibility for housework and for taking care of children and aged parents. While carrying out fieldwork in two counties in

22. Employment in construction enterprises increased from 9.12 million in 1985 to 31.3 million in 2007 (see National Bureau of Statistics, China Statistical Yearbook 2008, op. cit., p. 579).

23. See Sylvie Démurger, Marc Gurgand, Shi Li, and Ximing Yue, "Migrants as second-class workers in urban China? A decomposition analysis," Journal of Comparative Economics, vol. 37, no. 4, 2009, pp. 610-628.

24. See National Bureau of Statistics, China Statistical Yearbook 2006, Beijing, China Statistical Press, p. 104. 


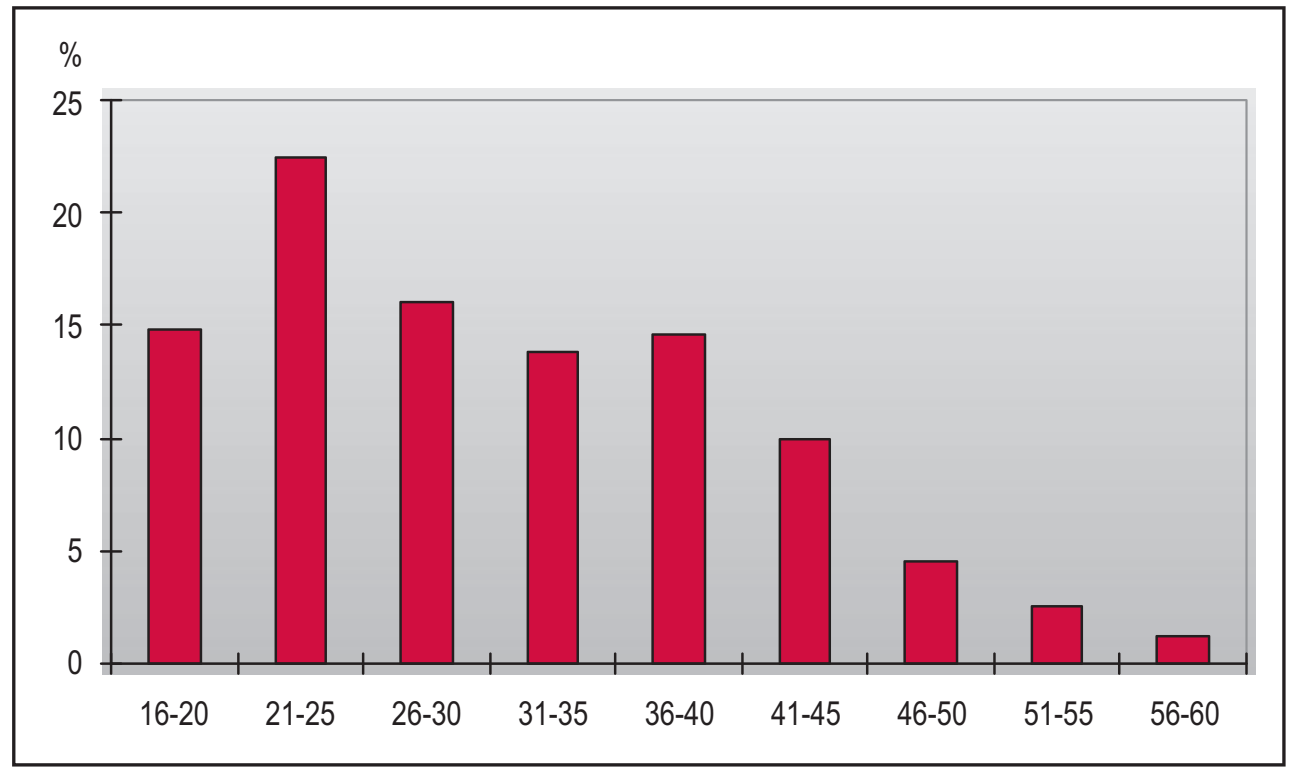

Sources: RUMS (2007)

Sichuan, the author asked some returned female migrants why they came back rather than staying with their husbands in the cities. The most frequent answer was "to take care of children and sick parents." Since it is difficult for migrant children to gain access to public schools in urban areas, the majority remain in their villages for schooling. It is estimated that two-thirds of the children of migrant families remain in villages. Fulfilling family duties is therefore a major reason for the lower propensity for rural females to migrate. The implication is that improving the access of migrant children to urban public schools would lead to a higher female ratio among rural migrants.

Another characteristic of rural migrant workers is their low educational attainment. The RUMS data indicate that 56 percent were lower-middle school graduates and 14 percent had an educational level of primary school or below in 2007. That means that 70 percent of migrant workers did not go beyond the nine years of compulsory schooling. In rural China, the enrolment rate in uppermiddle school (years 10-12) is low, although it has been increasing slightly. The low educational attainment of rural migrant workers implies that they enter the labour market as unskilled workers and that they need job training.

\section{Challenges and problems faced by rural migrant workers}

Although the Chinese government has recently made great efforts to improve the social and economic environment of rural migrant workers, they still face many problems and difficulties. Because of the hukou system, rural migrant workers are discriminated against in the urban labour market and are regarded as "second class citizens" in urban society. ${ }^{(25)}$ There are also many challenges in implementing government policies to eliminate discrimination against migrant workers and guarantee their equal access to public services in urban areas.

\section{Wage levels and wage growth}

The first problem faced by rural migrant workers is their low income. Given the large number of rural surplus labour moving to the cities, the labour market for low-skilled workers principally consists of rural migrant workers, making the search for jobs very tough. This kept wages at a subsistence level throughout the late 1980s and in the 1990s. Several surveys indicate that the average nominal wage level of rural

25. See S. Démurger, M. Gurgand, S. Li, and X. Yue, "Migrants as second-class workers in urban China? A decomposition analysis," art. cit. 
Figure 6. Distribution of rural migrant workers by educational attainment, 2007
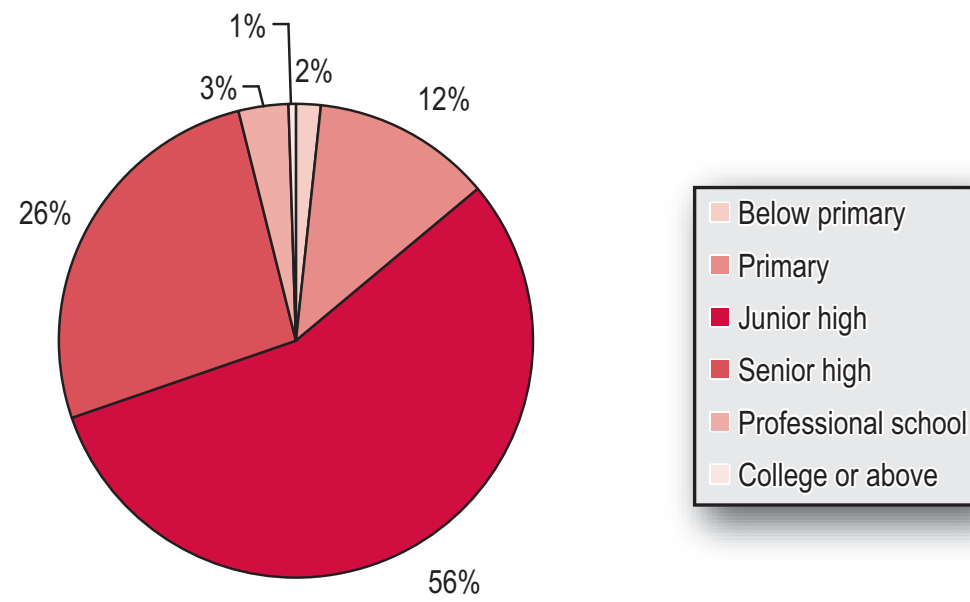

migrant workers did not increase in the Pearl River Delta until the end of the 1990s, meaning that the real wage decreased considerably during that period. ${ }^{(26)}$ Even in 2002, the average monthly wage of migrant workers was US\$100, which was 58 percent of the average wage of urban workers. Owing to the decline in real wages, rural migrant workers have to take jobs with longer working hours, which lowers their hourly wage even more significantly. A survey conducted in Henan, Hunan, and Sichuan provinces shows that the hourly wage for migrant workers is about one quarter that of local urban workers. ${ }^{(27)}$

Moreover, taking into account income inequality among rural migrant workers, a large proportion is earning even lower wages. Some migrants earn what is equivalent to the official minimum wage, which is set at an unusually low level in some cities. ${ }^{(28)}$ The RUMS data indicate that around 35 percent of migrant workers earned less than US $\$ 150$ per month, 31 percent earned between US\$150 and $\$ 225$ per month, and only 15 percent earned more than US $\$ 300$ per month in 2007 (See Figure 7). Fortunately, the wage level of rural migrant workers has increased considerably over the last three years due to the shortage of unskilled labour in the coastal region. RHS_NBS data indicate that the average wage of migrant workers rose by 10 percent in 2006 and by 16 percent in 2008. ${ }^{(29)}$ The wage of rural migrant workers nevertheless remains considerably lower than that of local urban workers. For instance, RUMS data indicate that the average monthly wage of rural migrant workers is about 54 percent that of urban local workers, and the hourly wage is only 39 percent. ${ }^{(30)}$

\section{Job insecurity: Unemployment and job mobility}

Generally speaking, migrant workers have a fairly low rate of unemployment, partly because their low income does not allow for long-term unemployment in the urban areas. According to CHIPS data, the unemployment rate among rural migrant workers was less than 3 percent in 2002, compared with 10 percent among local urban workers. ${ }^{(3)}$ However, a low unemployment rate does not mean low job mobility for migrant workers; their

26. Project Team of Research Office, State Council, Research report on rural migrant workers in China, op. cit.

27. Ibid.

28. Ibid.

29. National Bureau of Statistics, Continuing rise of rural out-migrant workers in 2006, Internal Report, Feb. 2007; National Bureau of Statistics, The total number of rural nonagricultural workers reached 225 million at the end of 2008, 2009, http://www.stats.gov.cn/tjfx/fxbg/t20090325_402547406.htm.

30. Quheng Deng and Shi Li, "Wage Structure and Inequality of Local and Migrant workers in urban China," in X. Meng and C. Manning, The Great Migration, Northampton (USA) Edward Elgar, 2010.

31. Shi Li and Quheng Deng, "Re-estimating unemployment rates in urban China," Jingjixue Dongtai (Currents in Economy), 2004.

32. John Knight and Linda Yueh, "Job Mobility of Residents and Migrants in Urban China," in S. Li and H. Sato, Unemployment, Inequality and Poverty in Urban China, Routledge, 2006. 


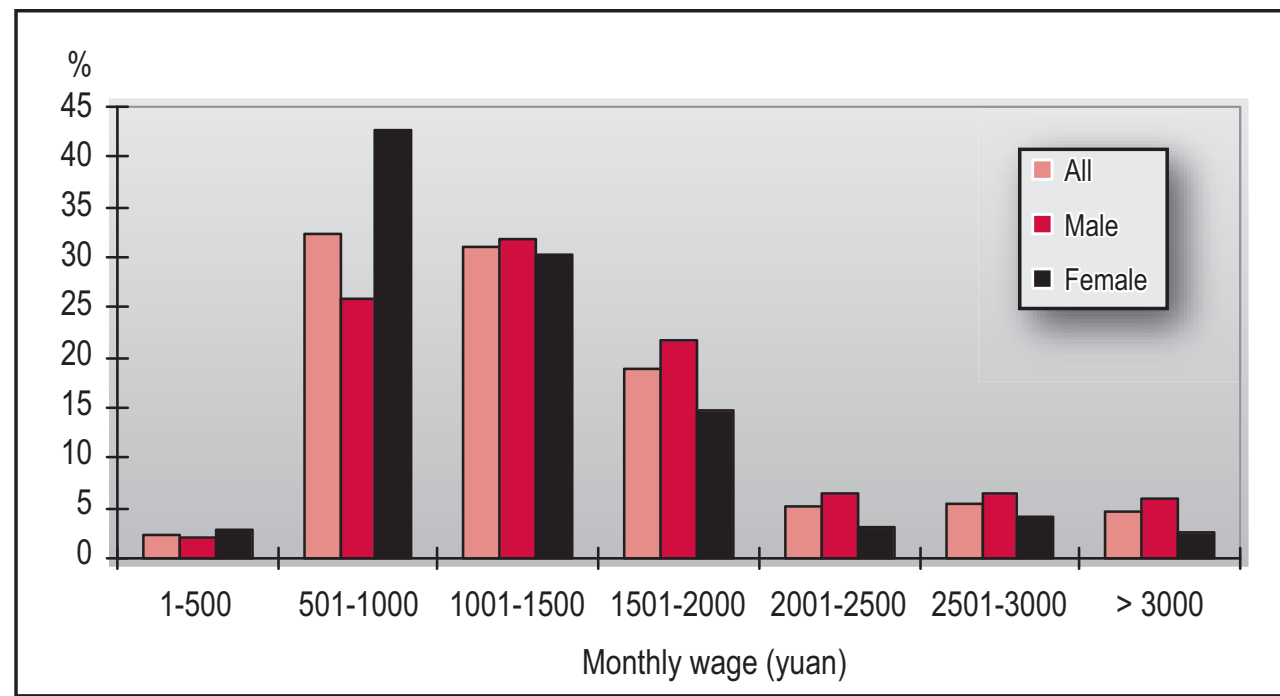

Sources: RUMS (2007)

job mobility is much higher than that of local urban workers. ${ }^{(32)}$ The 2002 CHIPS data indicate that nearly 98 percent of rural migrant workers had changed jobs since moving to the city, and two-thirds had changed jobs more than twice. The high mobility of rural migrant workers results partly from their concentration in the unskilled labour market, where competition is very strong, and partly from their lack of information on the nature of their jobs. To some extent their first jobs are like pilot jobs. When migrant workers in the 2002 survey were asked why they left their previous job, 41 percent chose low income, 15 percent the instability of the job, and 8 percent bad working conditions.

Another aspect of job insecurity is the low proportion of migrant workers having contracts with their employers. In 2004, 79 percent of migrant workers had no signed labour contracts. ${ }^{(33)}$

\section{Working conditions}

The majority of migrant workers work longer hours and more days per week than local urban workers. The 2002 CHIPS data show that over 80 percent of rural migrant workers worked seven days per week, and only 7 percent worked five days in accordance with the officially mandated working days for local urban workers. Moreover, the data also show that migrant workers had longer working hours each day. One third of migrant workers had to work 9-10 hours per working day, almost one quarter 11-12 hours per working day, and 12 percent more than 12 hours per working day. Less than 30 percent of migrant workers had working hours equal to or less than the legally mandated eight hours per day.

\section{Social security}

Local urban workers in the formal sector (officialy registred in working units) are entitled to social security benefits such as pensions, unemployment insurance, medical insurance, and public housing subsidies. Do rural migrant workers enjoy the same benefits? A survey conducted by the Ministry of Agriculture in 2005 shows that only 13 percent of rural migrant workers were covered by on-the-job-injury insurance, 10 percent were covered by medical insurance, and 15 percent by a pension scheme. ${ }^{(34)}$ Data from the 2002 CHIPS and the 2007 RUMS also provide some answers to this question. The data indicate that only 5 percent of migrant workers were covered by a pension scheme, less than 2 percent by unemployment insurance, and 3 percent by city medical insurance in 2002, while the figures are 18 percent, 11 percent, and 10 percent respectively for 2007. Not sur-

33. A survey conducted in 40 cities by the Ministry of Labour and Social Security in 2004 presents an even lower proportion of migrant workers with job contracts at only 12.5 percent (see Project Team of Research Office, State Council, Research report on rural migrant workers in China, op. cit., p. 13).

34. Ibid. 
prisingly, there is a striking contrast between the social security entitlement of rural migrant workers and local urban workers. As the 2007 RUMS data show, the corresponding figures for urban local workers are 60.1 percent, 36.8 percent, and 58.7 percent.

The problem of lack of social protection for rural migrant workers arises mainly from discrimination and inappropriate institutional arrangements against migrant workers, which do not require employers to provide social security to migrant workers or give incentives to migrant workers themselves to participate in available programs.

\section{Conclusion}

This paper provides a description of the current state of rural migration in China and discusses a number of issues and problems faced by rural migrant workers and challenges faced by the Chinese government, with updated data. $\mathrm{Mi}$ grant workers as a group are younger than local urban workers, males make up the majority, and they generally have low educational attainment. They come from all regions and provinces, either pulled by higher wages in urban areas or pushed by surplus labour in rural areas. Although the average income they earn in cities is much higher than from farm work in the countryside, many draw wages below or close to the urban minimum wage. The majority of migrant workers face insecurity in terms of employment, income, social protection, and so on. Compared with local urban workers, mi- grant workers have lower incomes, an even lower wage rate, significantly less coverage by social security, and less access to public services in urban China. The financial crisis in 2008 affected employment of migrant workers more severely at the beginning, although job opportunities for migrant workers rebounded quickly after the Chinese government immediately implemented a stimulus package. That means migrant workers are the most vulnerable group in the labour market when encountering external shocks.

The problems above also imply major challenges for the Chinese government. Although government policies have changed dramatically in recent years, from preventive and discouraging to more supportive and encouraging, and the actual situation of migrant workers has been slowly improving, it will take a long time for the Chinese government to change the situation completely and provide migrants with the same opportunities and rights as local urban people in terms of employment, payment, working conditions, social security, access to housing, and political rights.

\section{Glossary}

hukou

户口

li tu bu li xiang

liu dong ren kou guan li fei

wai lai wu gong ren yuan wu fu fei

zan zhu fei

zan zhu zheng

\section{离土不离鄉}

流動人口管理費

外來務工人員務付費

暫住費

暫住証 